\title{
InJection Molding Process Optimization
}

\author{
StANEK, M.; MANAS, M. \& MANAS, D.
}

Abstract: Optimization of injection molding process serves for finding ideal conditions during production of parts and observing their dimensions, shapes and properties. It is possible to determine the appropriate injection pressure, velocity, value and time of pacing pressure, etc. by optimization. The paper is dealing with description of Moldflow MPX system and its usage in optimization of injection molding process on real part.

Key words: injection molding, optimization, MPX, process
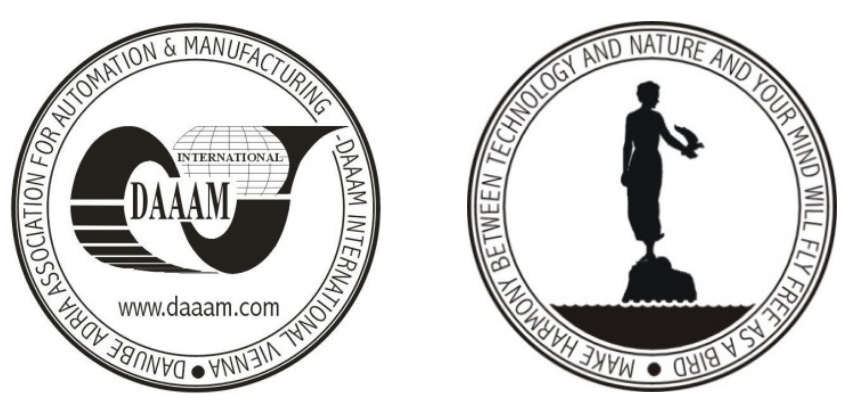

Authors' data: Dr. Stanek, M[ichal]; Manas, M[iroslav]; Dr. Manas, D[avid], Tomas Bata University in Zlin, TGM 275, 76272, Zlin, CZ, stanek@ft.utb.cz, dmanas@ft.utb.cz

This Publication has to be referred as: Stanek, M[ichal]; Manas, M[iroslav] \& Manas, D[avid] (2008). Injection Molding Process Optimization, Chapter 68 in DAAAM International Scientific Book 2008, pp. 839-854, B. Katalinic (Ed.), Published by DAAAM International, ISBN 978-3-901509-66-7, ISSN 1726-9687, Vienna, Austria DOI: $10.2507 /$ daaam.scibook.2008.68 